\title{
North-directed Triassic nappes in Northeastern Vietnam (East Bac Bo)
}

\author{
Claude Lepvrier $^{a}{ }^{*}$, Michel Faure ${ }^{b}$, Vuong Nguyen Van ${ }^{c}$, Tich Van Vu ${ }^{c}$, Wei Lin ${ }^{d}$, Thang Ta Trong ${ }^{c}$ \\ and Phuong Ta Hoa ${ }^{\mathrm{c}}$ \\ a Institut des Sciences de la Terre de Paris (ISTeP), UMR CNRS 7193, UPMC, 4 Place Jussieu, 75252 Paris \\ cedex 05, France
}

b Institut des Sciences de la Terre d'Orléans (ISTO), UMR CNRS 6113, Université d'Orléans 45067 Orléans cedex 2 France

c Faculty of Geology, Hanoi University of Science, 334 Nguyen Trai, Thanh Xuanh, Hanoi

d State Key Laboratory of Lithospheric Evolution, Institute of Geology and Geophysics, Chinese Academy of Sciences, Beijing, China

Abstract

A careful re-examination of the previous tectonic descriptions and the acquisition of new structural and kinematic data have been undertaken in northeastern Vietnam. The structure of the area consists of a system of slightly metamorphosed but ductilely deformed nappes, including recumbent folds, formed during the Triassic, prior to the unconformable deposition of the Upper Triassic terrigenous sediments. These results confirm the previous interpretation of « preyunnanaises nappes », represented by Middle-Upper Paleozoic foliated limestone resting through a flat mylonitic contact over an intermediate « Song Mien unit » (Deprat, 1915), the latter made essentially of deformed Lower Triassic sedimentary and volcanic formations, which previously filled the Song Hien rift (Bourret, 1922). In the external part of the belt, the Triassic strata conformably overlie slightly deformed and unmetamorphosed Upper Paleozoic rocks, forming an autochthonous domain. Alternatively, the same Triassic succession can be seen resting tectonically through décollement zones, directly over the Middle Paleozoic marbles, to form a distinct but subsidiary allochthonous unit. Our data show that the Song Chay orthogneiss and its Lower Paleozoic sedimentary country rocks belong to the main nappe. They also demonstrate that this nappe was transported to the N-NE. A newly discovered mélange of supposed oceanic nature and 
Triassic age, lying along the Song Chay Fault North of the Nui Con Voi, could hypothetically represent the rooted zone of the nappe. A Tertiary tectonic overprinting, in particular accommodated by strike-slip movements, likely accounts for the present orocline of NE Vietnam.

Keywords: northeastern Vietnam, South China Block, Triassic tectonics, ophiolitic mélange zone, ductile shearing, décollement

Corresponding author. E-mail address: claude.lepvrier@upmc.fr

\section{Introduction and historical background}

The late Tertiary and present-day boundary, between modern Indochina and South China tectonic units, runs along the NW-trending Red River Fault Zone (RRFZ) which, in the Oligo-Miocene, moved left-laterally, as a consequence of the continental extrusion of Indochina (Tapponnier et al., 1986). The Vietnamese segment of the RRFZ is located to the SW of the Day Nui Con Voi, an elongated metamorphic ridge, bounded by the steeply dipping Song Hong (Red River) and Song Chay strike-slip faults, to the SW and NE, respectively.

The Triassic boundary between the Indochina and South China blocks, among other continental pieces of East Asia (Metcalfe, 2002), lies further south and classically corresponds to the Song Ma suture. The amalgamation between these two Gondwana-derived crustal pieces of South East Asia took place during the Lower Triassic Indosinian Orogeny in the 245-240 Ma time interval (Lepvrier et al., 1997, Lepvrier et al., 2008). There, an oblique dextral collision is thought to have followed an oceanic then continental subduction zone, most probably N-dipping (Lepvrier et al., 2008) - but the vergence is not clearly established - marked by the generation of HP metamorphic rocks (Nakano et al., 2008; 2010). However, the oceanic material along the suture zone, which is attributed to the Paleotethys Ocean, is not yet dated with certainty and a simple Triassic reactivation of a previous subduction, by docking of the Sibumasu block (Metcalfe, 2002), cannot be excluded (Carter et al., 2001, Carter and Clift, 2008).

North of the Day Nui Con Voi high-grade metamorphic ridge, northeastern Vietnam (East Bac Bo) is geologically similar to the South China continental margin. This large area consists of deformed sedimentary and metasedimentary rocks, associated with volcanics and intrusives (fig.1). Investigations by Vietnamese and 
Russian geologists have been undertaken in various domains during the 1970 and 1980 decades (Dovjikov, A.E., 1965; Staritskiy et al., 1973; Morgunov, 1970; Kat, 1972). These works included regional mapping, igneous petrology and geochronology (GDMGV, 1973, 1979; GDMGV, 1988). Geological syntheses concerning Indochina and South East Asia have been published in the same period (Hutchison, 1982; Fontaine and Workman, 1978). More recently, detailed stratigraphic and paleontologic studies, realized by Vietnamese geologists, have been published in an exhaustive and modern compilation (VNUPH, 2006). Other investigations have been carried out on magmatic petrology and metallogeny (Tran Trong Hoa et al., 2004, 2008). Meanwhile, 1:200,000 scale geological maps have been published (DGMV, 2000, 2001; Ma Quan, Bao Lac, Chinh Si/Long Tan, Tuyen Quang, Bac Kan, Bac Quang, Lang Son, Lao Cai sheets). However, very few specific tectonic researches have been conducted during recent years, except in the Song Chay Massif and its Chinese Du Long counterpart (Roger et al., 2000; Maluski et al., 2001; Yan et al., 2006).

By contrast, North Vietnam - at that time known as Tonkin - was extensively explored during the colonial period, as soon as the beginning of the last century, by French geologists from the « Service géologique de l'Indochine ». The first important tectonic contribution at that time came from J. Deprat (1915), who mapped a large part of the area and gave spectacular cross sections throughout Yunnan and Northeast Tonkin. In a series of papers published in the 1910' decade and concluded by an important Memoir with 1:100, 000 maps (Pa-kha, Ha-giang, Yên-minh and Ma-Li-Po) and a short note related to the Bao Lac and Cao Bang areas, Deprat (1915, 1917) described the structure of northeastern Tonkin as a stack of recumbent folds and nappes, named « nappes préyunnanaises ", lying to the North and East over autochthonous terranes, through an intermediate allochthonous unit, which he called « nappe de Song Mien ».

The tectonic descriptions and interpretations of Deprat were judged doubtful and then subjected to a systematic re-examination, just after he was obliged to leave Indochina in 1919 and to stop his career of geologist. Although in disagreement with Deprat on several points, Jacob and Bourret (1920) and Bourret (1922) maintained the allochthonous interpretation but the internal deformation style with large recumbent folds and ductile shear surfaces was no longer accepted. Jacob and Dussault (1925) also acknowledged the idea of nappes, but only as the consequence of superficial movements. Finally the nappe concept disappeared in the modern descriptions of the East Bac Bo structure, represented only by steeply dipping faults, and upright folds affecting the upper crustal level (DGMV, 2000, Ma Quan, Bao Lac sheets). 
Recent tectonic fieldwork has been conducted in NE Bac Bo, revisiting several outcrops, checking the cross sections published by Deprat (1915) and Bourret (1922) and collecting new structural and kinematic data. Preliminary conclusions have been already reported (Lepvrier et al., 2009). In this paper, we present the results of our study and emphasize the convincing evidence that confirm the existence of ductile Triassic nappes in northeastern Vietnam and the tectonic style represented in the Deprat's sections. In addition, the involvement of the Song Chay massif in the nappe system is demonstrated, the north-directed transport direction of the main nappe is established and its root zone, along a newly defined suture zone along the Song Chay fault, is suggested. The new structural and kinematic data provided in this study should significantly improve the understanding of the Triassic tectonics of northern Vietnam and allow fruitful correlations with the geodynamic evolution of South China.

\section{Geological outline of NE Vietnam (East Bacbo area)}

\subsection{Stratigraphic succession}

The western part of the study area in Northern Vietnam is occupied by the huge Song Chay massif (figs.1, 2), which culminates at 2431m (Tsi - Con - Ling summit). It is mainly composed of augen-gneiss derived from a porphyritic monzogranite emplaced at 420Ma, according to U-Pb zircon age (Roger et al., 2000). The surrounding sedimentary succession (figs.1, 2), is chiefly represented by Upper Proterozoic and Paleozoic to Triassic rocks, distributed in several geological formations, which display generally marine facies. The carbonate-dominated Middle to Upper Paleozoic rocks, either unmetamorphosed, as in the external part where consequently abundant fossils are preserved, or intensively deformed and transformed into marbles, produce spectacular karstic morphologies, well-known in Halong bay, in the Ba Be Lake area, and in the Dong Van and Cao Bang areas at the extreme north and northeast area of Vietnam.

Many geological formations have been identified and stratigraphically defined (VNU Publishing House, 2006). The Lower Paleozoic series forming, together with possible Upper Proterozoic rocks, the country rocks of the Song Chay orthogneiss, are represented by the Middle Cambrian Ha Giang formation and Upper Cambrian Chang Pung formation in the western part and Upper Cambrian Than Sa formation more to the east, both dated by trilobites and brachiopod assemblages. They mainly consist of terrigenous-carbonate and clastic sediments, corresponding to deposition in a shallow-marine environment, as the following Early Ordovician carbonate Lutxia formation. The Phu Ngu formation, dated by graptolites as Ordovician-Early Silurian, is made of terrigenous sediments. 
The Middle Paleozoic (Devonian) is marked in East Bac Bo by basal units, consisting of terrigenous terrestrial sediments with plants and fish-bearing red beds (Si Ka formation) which overlie unconformably the Lower Paleozoic deposits, in the absence of the Upper Ordovician and Silurian. The following Devonian succession is dominated by carbonates, from shelf facies in the Middle Devonian to pelagic ones in the Upper Devonian. In easternmost littoral Bacbo, terrigenous-continental sediments with fish fauna persist in the Do Son formation until the Middle Devonian (Givetian-Frasnian).

The Carboniferous and Permian formations in East Bac Bo are in continuity with the Upper Devonian ones. They consist of marine carbonates (limestone and siliceous limestone). Near the base of the Upper Permian Dong Dang formation, bauxite horizons indicate a period of uplift.

The Lower-Middle Triassic sedimentary rocks are found in the Song Hien zone (Bourret, 1922), and An Chau depression. The Lower Triassic formations lie on the Permian Dong Dang carbonate shelf deposits and consist partly of marine carbonates but mainly of terrigenous turbiditic sediments (conglomerates, sandstones, tuffaceous sandstones, siltstones, shales) forming a flysch succession. An important contribution of volcanic sediments and acidic effusive rocks took place in the Induan-Olenakian and especially in the Anisian.

The unconformably overlying Upper Triassic (Carnian and Norian-Rhetian) and Jurassic Formations are represented by littoral marine to continental molassic formations, deposited in shallow sea or continental environments, in a foreland setting. Abundant plants and freshwater remains, in coal-bearing (Hong Gai and Van Lang) and red beds (Ha Coi) facies deposits, are exposed in the Quang Ninh basin. Isolated outcrops exist more to the west, as for example to the North of Tuyen Quang to Cho Chu (Dinh Hoa) where red conglomerates and sandstones rest unconformably over the Devonian rocks and over the Cho Chu granitic massif.

Minor exposures of Upper Cretaceous red beds, resting over Middle Triassic deposits, are present in the Yen Binh basin, South of the Song Chay massif.

Neogene to Quaternary deposits are preserved along the Song Chay Fault in half-graben to rhombgraben basins. In a similar pull-apart setting other basins of the same age lie along the major strike-slip fault striking from Cao Bang to Lang Son (fig.1) and extending to Tien Yen on the northern coast of the Tonkin gulf.

\subsection{Magmatism}

Apart from the volcanic and volcanosedimentary Triassic material, various intrusions, generally forming 1 to 10 km-sized bodies, crop out in Northeastern Bacbo (Tran Trong Hoa et al., 2004, 2008). Some of 
these intrusions (Phia Bioc, Pia Oac) have been emplaced throughout the Paleozoic strata as post-tectonic bodies, developing thermal metamorphism with hornfels in the host rocks. This can be observed for example around Cho Don and along the Song Cau, near Bac Kan and around the Pia Oac. Other intrusions are deformed and foliated, as in the Pia Ma Massif, where syenites are transformed into nephelinitic gneiss (Bourret 1922; Fromaget, 1941). A few magmatic alkaline rocks are also found, as variously sized (1m to 500m) blocks, within the Lower Triassic sediments which filled the Song Hien rift basin; they are interpreted as olistoliths. Several demonstrative outcrops of those blocks can be seen along the section from Bao Lac to Cao Bang and in the vicinity of Cao Bang (fig.3.a, 3b). This Permo-Triassic alkaline magmatism is regarded as being produced under the influence of the Permian Emeishan mantle plume (Polyakov et al., 1999, Hanski et al., 2004, Tran Tronh Hoa et al., 2008) and to have allowed the initiation of the inferred Song Hien rift basin. It includes diversified petrologic rocks, comprising the following types:

- mafic-ultramafic association (layered lherzolites, gabbronorites and gabbro-dolerites) of the Nui Chua Complex in the Phu Ngu area, near Phu Luong and similar ultramafites and mafic rocks (Suoi Cun massif) in the Song Hien rift zone, near Cao Bang (fig.1). In the latter area, these alkaline rocks are thought to form a bimodal volcanoplutonic association including felsic material represented by rhyolites, rhyodacites and porphyry granites (Tran Trong Hoa, 2004).

- gabbroic and syenitic intrusives of various types, assigned to the same alkaline gabbro-syenite association (Tran Trong Hoa, 2004), represented in different massifs within the Lo Gam - Phu Ngu zones: syenites and gabbros near Luc Yen- Tan Linh (Yen Bai), Tich Coc (Tuyen Quang), Cho Don (Ban Phuc and Khuoi Loong) and more to the north the Pia Ma nepheline syenite (North of Ba Be Lake)

- Several aluminous granitic plutons: the Phia Bioc massif NW of Bac Kan, the Pia Ya granite more to the North, the Pia Oac leucocratic monzonite granite to the South of Tinh Tuc and the Phan Ngame granite in the central part of the Ngan Son antiform have been identified for a long time (Bourret, 1922; Fromaget, 1941).

\subsection{Structure}

This sedimentary and magmatic material of Paleozoic and Triassic ages is distributed in several structural units, bounded by thrust faults convex to the East, to form a large fold-and-thrust-belt structure (fig.1). A series of arcs and ridges (Phu Ngu Arc, Lo-Gam structure, etc.) has been defined (Bourret, 1922; Fromaget, 1941; Hoa et al., 2008. To the West of the Song Chay gneissic massif, the structures verge to the North in the direction of Ha Giang and Dong Van and Northeast towards Cao Bang. They turn progressively eastwards in the sector of Bac Kan and southeastwards in the Nui Bac Son range which develops from Thai Nguyen to Lang Son 
and then in the range which parallels the coast of Ha Long bay and Bac Bo (Tonkin) gulf, North of Haiphong. Finally, the system of curved faults connects laterally with an E-W to WNW-ESE strike-slip fault dominated system, subparallel to the Red River fault. Such an overall arcuate-shaped structural pattern, first recognized by Zeil (1907) and described as the «virgation du Nord-Est du Tonkin » (Bourret 1922, Jacob and Dussault, 1929), allows the distinction of an inner domain represented by the Son Chay massif in the WNW and a outer domain (external zones) towards South China and the Bac Bo (Tonkin) Gulf. North Vietnam therefore displays a usual fold-and-thrust belt style. This structural arrangement contrasts with the geometry of the Truong Son Belt in Central Vietnam, which is dominated by a set of WNW-ESE trending subparallel dextral strike-slip faults, formed during the Indosinian Orogeny (Lepvrier et al., 1997).

\section{The NE Vietnam nappe system: structure and kinematics}

Below the Upper Triassic unconformity, northeastern Vietnam (figs.1, 2) displays contrasted domains of deformation, as illustrated by the tectonic style of folding expressed into the Middle-Upper Paleozoic carbonates (Deprat, 1915). The outer part of the fold-and-thrust belt, which largely extends in South China, represents an autochthonous domain, slightly deformed by upright to slightly inclined folds and unmetamorphosed. The inner and medium parts, represented by the Song Chay Massif and the surrounding sedimentary formations extending to the North and East, correspond to an allochthonous weakly metamorphic domain, ductilely deformed at various scales by isoclinal recumbent folds.

\subsection{Autochthonous domain}

From the Dong Van area (North of Yen Minh) to the Northeast and East of Cao Bang and more to the South in the- $\mathrm{Na}$ Ri and Nui Bac Son ranges and towards Haiphong city and Ha Long bay, the deformation observed in the Paleozoic and Lower-Middle Triassic succession, as a result of Triassic events, is weak and only concerns the upper crustal level. This folding phase overprints a pre-Devonian, Lower Paleozoic event, largely developed in South China (Grabau, 1924, Ren, 1964, 1991; Zhao et al., 1996; Faure et al., 2009; Charvet et al., 2010), marked by the unconformity of the Lower Devonian Si Ka Formation (VNU, 2006), as that can be observed along the road from Dong Van to Lung Cu (China-Vietnam border) and to the northeast of Cao Bang. At outcrop scale, the Triassic deformation style is essentially characterized by upright to slightly inclined folds (fig.3.g) and by reverse faults. Open folds characterize the thick beds of the Carboniferous carbonates whereas tight folds affect the thin-bedded Si Phai and Toc Tat Devonian limestones (fig.3.h) (VNUPH, 2006). This strong 
disharmony of folding, due to contrasted lithology between massive and thin-bedded carbonates, may give rise to an apparent unconformity. However, this feature does not correspond to a pre-Carboniferous tectonic event. As a result of progressive upright folding, the Devonian formation is locally cut by reverse faults (fig.3.i). A slaty cleavage, subparallel to the axial planes of axial planar to the folds, develops in the shaly, more incompetent material, of the Devonian formations (fig.3.j) and in the Lower Triassic succession.

At regional scale, due to the general oroclinal bending, the fold trend varies. In the North and Northeast, the fold axis direction is WNW-ESE to NW-SE. To the Southeast, the folds, associated with cleavage and thrusts, strike NE to ENE and involve Upper Triassic rocks, up to the Cretaceous sedimentary rocks that fill the An Chau depression, north of Haiphong. The orocline might be the consequence of a superimposed Tertiary shortening event, coeval with strike-slip movements and Neogene pull-apart development along the Cao Bang-Lang SonTien Yen fault zone.

\subsection{Allochhtonous domain: the northeastern Vietnam nappe}

A large significant part of northeastern Vietnam is covered, North and East of the Chay River,oecepied by a major nappe (figs.1, 2), comprising several stuctural units, which has been ductilely deformed during the Triassic, prior to the Upper Triassic unconformity. From the Song Chay Fault zone to the frontal thrust, at a distance of about $130 \mathrm{~km}$, this northeastern Vietnam nappe occupies a surface of approximatively $15000 \mathrm{~km}^{2}$ and eam be structurally subdivided in sub units. The lower sub unit is represented In the inner part of the system the nappe includes the Song Chay orthogneissic massif itself and its Lower Paleozoic host rocks. The outer part, dominantly composed of metasedimentary calcareous material of Middle to Upper Paleozoic age and involving locally gneissic rocks, forms an upper sub-unit, correspondsing to the « preyunnanaises nappes » (Deprat, 1915) and to the « Song Gam nappe » (Bourret, 1922). Locally, north of Ha Giang, occurs the equivalent thrust sheet named « lame du Col des Partisans » (Jacob and Bourret, 1920).

Another displaced unit corresponds to the sø-called «nappe intermédiaire de Song Mien » described by Deprat (1915), who wrongly correlated the schists of Song Mien with the Lower Paleozoic schists of Song Lo, beneath the "preyunnanaises nappes". As recognized later, the Song Mien schists of Deprat are Lower Triassic in age, and equivalent to the Song Hien schists of Bourret (1922), outcropping in the Cao Bang area. This material, which fills the Song Hien rift basin, belongs to the Lower Triassic (Induan and Olenekian) Song Hien Formation (VNUPH, 2006) made of argilleous shales with interbedded felsic effusives in the lower part. In order to avoid confusion, the name "nappe intermédiaire de Song Mien” of Deprat is no longer used in the present paper and is 
replaced by "Song Hien nappe". The Song Hien nappe is sandwitched in between the allochthonous and autochthonous domains but also can be seen resting on décollement surfaces over the main nappe and over the autochthonous material.

\subsubsection{The Middle - Upper Paleozoic material unit sub-unit}

The basal thrust contact of the Northeast Vietnam nappe is well-exposed to the North of Ha Giang, near Nam La, Dong Thuong and Lung Ho (fig.1, fig.4.a). It corresponds to the northwards thrusting of the DevonianCarboniferous foliated carbonate onto the Lower to Middlle-Triassic turbidite cropping out in the area of Yen Minh and Song Nhiem (fig.2). The contact is represented by a flat to slightly dipping mylonitic zone, with a thick sole of mylonitic marbles (fig.4.b), which was reported for the first time by Deprat (1915). Several ductile contacts can be recognized within the metasedimentary pile. The nappe front (fig.4.a), trending WNW-ESE, can be followed from the Chinese border to Quan Ba and eastwards to Song Gam; then it turns to the Southeast and South. Frequently, the primary basal ductile contact has been reworked and cut by a steeply dipping brittle reverse fault, as it can be observed along the road from Quang Ba to Yen Minh or along the section of Song Gam from Bao Lam to Bao Lac. It is worth noting that only this steep fault is represented on the cross-sections of the Ma Quan and Bao Lac, 1:200,000 geological maps. Moreover, some segments of the fault exhibit normal facets, resulting from recent uplift. Between Na Phac (along Song Nang) and Bac Kan and more to the South to Cho Moi, this brittle fault and other subparallel faults, clearly showing traces of recent reactivation, bounds to the east the Early Paleozoic of the Phu Ngu structure, and affects the eastern border of the Phia Bioc granite (fig.1).

East of Song Nang and Song Cau, in the Nui Ngan Son and Nui Tong Tinh massifs (the latter surrounding the Pia Oac intrusion), the Upper Paleozoic rocks are also part of the Northeastern Vietnam nappe system but form a distinct sheet (fig.1). This isoclinally deformed sheet has been secondarily folded in a large antiform and appears beneath the Triassic schists of the Song Hien nappe (fig.2), as pointed out by Bourret (1922).

Throughout the nappe, the involved material, dominantly calcareous and transformed into marbles, is strongly foliated, intensively folded and affected by mylonitic shearing.

A main foliation, S1, affects the entire sedimentary pile and develops parallel to the axial planes of isoclinal and sheath folds (figs.4.c to 4.e). The S1 foliation contains sericite, rarely biotite, with a grain arrangement defining a mineral lineation L1 (figs.4.g, 4.h). Asymmetrical boudinage of quartz lenses can be observed as well 
as the development of synkinematic quartz pressure shadows around pyrite grains. In the Devonian marble of the Ngan Son area, elongated coral and crinoid fossils define L1. The mineral and stretching lineation throughout the nappe strikes consistently $\mathrm{N}$ to NE (fig.1). Various kinematic criteria (S-C structures, asymmetric quartz lenses or veins, asymmetrical tails around pyrite grains) indicate a top-to-the-north sense of shear.

Recumbent subhorizontal folds, up to decametric in scale, are widely distributed and can be observed particularly in the Lower Devonian Mia Le Formation outcropping in the Ba Be lake area (fig.4.c), and along Song Gam in the vicinity of Bao Lam (fig.4.d). In the cherty limestones outcroppping in the Ba Be lake area, Bourret (1922) noticed curious cherts « en fer à cheval» (horseshoe shaped), but did not recognize them as hinges of isoclinal folds preserved in siliceous beds. This type of folding also characterises the Devonian metamorphic limestone forming the Ngan Son and Nui Tong Tinh massifs, from Na Phac to Na Ban village West of the Pia Oac granite and the massif extending East of Bac Kan to Na Ri. An equivalent style of deformation represented by sub-isoclinal folds affects the Lower Paleozoic material of the Phu Ngu formation, as this can be observed in the cliffs East of Bac Kan and along the road from Ha Giang to Bac Me (Figs 4.i and 4.j). These folds, corresponding to the main folding phase coeval with nappe emplacement, have two distinct trends (fig.1). A part of them strikes N-S, parallel to the regional stretching lineation, forming "a type" folds. This feature seems to be well developed in the southern, inner part of the nappe, North of the Song Chay Fault; however, true sheath folds with closed surface has not been observed yet. More generally, in the external upper part of the nappe, N-NE verging, E to ESE striking folds, perpendicular to L1, are conspicuous.

The S1 foliation has been later microfolded. A second generation of upright folds, metric to decametric in scale can be observed, as well as a crenulation lineation L2 (fig.4h); the dominant trend is N-S (fig.1). Locally the crenulation foliation S2 is itself refolded by another set of crenulation cleavage striking E-W. These minor structures reflect the refolding of the nappes.

\subsubsection{Song Chay orthogneiss and Lower Paleozoic unit}

To the North of the Nui Con Voi, between the NW-trending Song Chay and Wenshan-Malipo strikeslip faults, the Song Chay orthogneissic massif (Fig.1), which straddles the South China - North Vietnam border, forms an asymmetrical NE-SW metamorphic antiform (fig.2), with a foliation steeper to the East than to the West. The antiformal shape results from the folding of an initial flat-lying foliation (S1), preserved on the top of the structure (around Xin Man and Hoang Su Phi). The overlying metasedimentary rocks of Lower Paleozoic age, observed in the area, do not correspond to cover rocks separated fom the gneissic core by any detachment 
surfaces but to the host rocks of the original granite. Therefore, the Song Chay massif doesn't represent a metamorphic core complex, as it has been generally interpreted (Maluski et al., 2001; Yan et al., 2006). The final uplift of the massif was achieved in the Tertiary (Maluski et al., 2001).

The central part of the massif is chiefly composed of augen-orthogneiss derived from a porphyritic granite, which has been emplaced during the Lower Paleozoic, and has been, metamorphosed in the upper greenschist to lower amphibolite facies (Roger et al., 2000; Maluski et al., 2001; Yan et al., 2006). According to thermochronology, the deformation occured between 300 and $500^{\circ} \mathrm{C}$, and metamorphic thermobarometric estimates for the deformation indicate ca $580^{\circ} \mathrm{C}$ and $5 \mathrm{kbar}$, corresponding to a $15 \mathrm{~km}$ depth (Roger et al., 2000). The Upper Proterozoic to Lower Paleozoic sedimentary host rocks are similarly metamorphosed, with sericite, chlorite and quartz assemblage. The deformation pattern is the same in the gneissic core and the metasedimentary envelope.

In the orthogneissic core, the deformation is characterized by a pervasive, flat-lying S1 foliation, including mylonitic zones produced during the northward thrusting. However, undeformed relics of the original granitic intrusion are locally preserved. The primary foliation bears a mineral and stretching lineation L1. In some locations, the rock fabric is more linear than planar, and indicates a constrictional shape of the strain ellipsoid (Maluski et al., 2001). L1 lineation trends N-S to NNE in average (fig. 1), although N-W trending directions can be measured locally, as for example along a fault line on the way from Bac Quang to Hoang Su Phi. Various kinematic indicators (shear bands, asymmetrical K-feldspar porphyroclasts) clearly define a top-tothe-north sense of shear (figs.5.a; 5.b). To the South of the antiform, as shown along the road to Xuan Minh, the foliation and lineation steepens, dipping $40^{\circ} \mathrm{S}$ (figs.1 and 2). Shear criteria still indicate northward thrusting movements, (fig.5.c). The same direction and top-to-the-north sense of shear, but along a northward dipping foliation, can be observed on the northern flank of the massif.

In the metasedimentary country rocks that surround the gneissic material, a similar deformation pattern can be identified. This is particularly clear in the western flank of the massif along the road from Pac Ngam to Bac Ha and Xin Man (Coc Lai), within the Cambrian and Ordovician muscovite-bearing marbles alternating with pelitic schists (fig.5.e). The dip of S0 and S1 planes is $30-50^{\circ} \mathrm{W}$ and becomes $20^{\circ} \mathrm{N}$ to subhorizontal in the Xin Man area. This material is deformed, at least at metric scale, by N-trending isoclinal folds (fig. 5.g) and displays a N-S mineral-stretching lineation L1. Asymmetric pressure shadows around pyrite grains, sigmoidal quartz lenses, and boudins define a top-to-the-north shear sense (fig.5.f). Qualitatively, the deformation intensity 
increases downwards, marked by more and more penetrative shear planes, and locally mylonitic zone close to the interface with the gneiss, as displayed in the Xin Man area. According to our observations there is no equivalent to the detachment fault reported by Yan et al. (2006) in the Chinese Dulong massif. Thes evidence for an extensional metamorphic core complex is lacking in the Song Chay massif.

The same conclusion can be drawn from the eastern flank of the anticline, in the steeply dipping Cambrian to Devonian metasedimentary formations, which are exposed along the road from Bac Quang to Vi Xuyen and Ha Giang. Cambrian quartzites, South of Bac Quang, bear a subhorizontal stretching lineation, with a left-lateral shear sense compatible, prior to the formation of the antiform, with a top-to-the-north transport direction. In the same area near Vi Xuyen, E-dipping Devonian marbles display N-directed fold axes (fig.5.h).

As in the Middle to Upper Paleozoic sedimentary part of the nappe, the S1 foliation on the Song Chay massif has been refolded at various scales to give rise to the large antiform that shapes the massif (fig.2), whereas the Lower Paleozoic sedimentary rocks, around the gneissic core, are similarly affected by upright folds and crenulation. A S2 axial planar crenulation cleavage can be seen in some places, as for example near Xin Man. L2 lineation generally strikes NS in average in the E and W parts of the massif and around E-W in the northern part (fig.1). These two sets of lineation likely reflect the refolding of the Song Chay nappe and the subsequent formation of a dome. Equivalent results have been reported from the Dulong massif in China (Yan et al., 2006).

In the Yen Binh area, the southern flank of the antiform is cut off by an E-W normal fault that delineates to the South a half-graben basin filled by the Middle Triassic (Anisian) Yen Binh Formation (VNUPH, 2006) and by Cretaceous continental red beds (figs. 1 and 2). S-C stuctures indicating a normal sense of shear, are preserved immediately in the footwall of the Yen Binh fault within the micaschists exposed along the Song Bac section (fig. 5.d), together with deformed granitic material. This normal fault likely represents a structure formed during the early stages of exhumation of the Song Chay nappe.

\subsection{3. other gneissic bodies}

The question of the involvement in the deformation of the Permo-Triassic plutons (see 4.2) that intrude the Paleozoic cover rocks up to the Upper Devonian has long been a matter of controversy. A large part of these plutons, such as the Phia Bioc granite, the Ban Phuc gabbro-syenite magmatic association ( $\mathrm{N}$ of Chodon) and the Pia Ya granite (Fig.1), are not affected by any ductile deformation, and thus appear as post-tectonic bodies, 
cross-cutting the ductile basal contact of the nappe (fig.2). They develop thermal metamorphism with an inner envelope of biotite-garnet hornfels. As claimed by Bourret (1922), the Pia Oac (figs 1, 2) leucocratic monzonitic granite, is similarly undeformed and does not represent a syntectonic massif, unlike the opinion expressed by Deprat (1917). By contrast, the Pia Ma Massif, as drawn and described by Deprat (1917) and Bourret (1922), is a foliated nepheline syenite transformed into orthogneiss, with hornblende porphyroclasts forming a mineral lineation (Fromaget, 1941). Our observations North of Da Vi (Fig.4.f) indicate that the Pia Ma massif has been involved in the same episode of deformation that affects the Devonian marbles.

\subsubsection{Conclusion}

In summary, the entire Paleozoic sedimentary and intrusive material lying North of the Song Chay Fault has experienced the same pre-late Triassic ductile deformation, and belongs to a single large nappe, transported to the $\mathrm{N}$ or NE. The initial flat or slightly dipping foliation, and the nappe basal contact have been refolded, during a second episode, to form large antiforms and synforms, and at minor scale to produce crenulation and upright folding. In particular, the Song Chay orthogneiss, together with its host metasedimentary rocks, has been sheared during such a Triassic event (and subsequently uplifted during the Tertiary), but the resulting dome shape does not have the meaning of an extensional metamorphic core complex. Along the northern border of the massif, the foliation in the gneiss and the Lower Paleozoic sedimentary rocks dips northerly beneath the Middle-Upper Paleozoic material, which forms the upper part of the nappe to the North of Ha Giang (Fig.2). Although this is not readable in the landscape because of the karstic morphology and the abundant tropical vegetation, the minor recumbent folds are obviously part of hectometer to kilometer-scale recumbent folds, as this has been drawn in the cross sections of Deprat (1915). The isoclinal folding likely explains the thickness of the sedimentary succession, as suggested by Deprat (1915) for the pseudo - monoclinal aspect of the Lower Paleozoic succession, on the western side of the Song Chay massif. The thickness of the Paleozoic metasedimentary succession, between the Song Chay fault and the southern border of the Song Chay massif (Fig.2) could be explained by the same reasons.

\section{3. the Implication of the Triassic in the deformation and the existence of a Song Hien nappe}

Different types of field relationships between the Lower Triassic and Upper Paleozoic formations have been recognized.

\subsection{1. stratigraphic continuity}


In the autochthonous external domain, the Lower Triassic strata (Song Hien, Hong Ngai and Lang Son Formations: T1 sh, hn and ls, DGMV, 2000) is in stratigraphic continuity with the Permian platform-carbonate layers represented by the Dong Dang (P2 dd) formation (DGMV, 2000). The flysch-like carbonate facies, displayed by the Triassic succession indicates a significant deepening of the basin. Both Upper Paleozoic and Triassic rocks are involved in the same upright to slightly NE vergent folding with sometimes the development of a slaty cleavage. This relationship can be seen to the North, in the Dong Van area, and to the Northeast of Cao Bang, or in the Southeast in the vicinity of Lang Son and Van Quan, and around Binh Gia. In other localities, the Lower Triassic has been deformed independently from the Upper Paleozoic, with differential tectonic movements between the two lithostratigraphic units.

\subsection{2 synsedimentary faulting}

Several lines of evidence argue for syntectonic sedimentation of the Triassic turbidites. This can be seen in several outcrops. East of Nari, also on the way to Meo Vac from the locality of Ly Bon on the Song Gam, the Lower Triassic turbidites are in fault contact with Upper Paleozoic limestone, and exhibits synsedimentary deformation features represented by slumps, discontinuous broken sandstone beds, olistoliths, indicating for slope instabilities. The original synsedimentary structures of this proximal deposit «wild flysch or flysch à blocs» has been later overprinted and deformed by subsequent Triassic tectonics, giving rise to foliated planes and shear zones (figs.3.c, 3.d).

To the East of Cao Bang, along the Cao Bang-Lang Son fault, the deformed Lower Triassic turbidites include olistoliths, represented by marbles and by various magmatic blocks of alkaline affinity (fig.3.b). In particular, pillow lavas are beautifully exposed (fig.3.a). This deposit results from a synsedimentary tectonic activity, which could have taken place along the faulted margin of the inferred Song Hien rift. The pillow lavas and gabbros, which are scattered as blocks within the Triassic turbidites along the road from Tinh Tuc to Bao Lac, are derived from Permian magmatism related to the Emeishan plume. The initial synsedimentary chaotic formation has been tectonized during the Triassic event and later on, in particular by the Tertiary strike-slip movements along the Cao Bang- Lang Son fault.

\subsection{3. ductile décollement.}

In the Ngan Son and Nui Tong Tinh ranges, the latter including the Pia Oac granite, and more to the South between Na Ri and the South-East of Na Phac, the Lower Triassic Song Hien formation rests directly over the 
Devonian rocks, both ductilely deformed, through a well-marked décollement zone. This relationship, already pointed out by Bourret (1922) can be seen at the eastern rim of the Ngan Son antiform where the Triassic schists tectonically overlie the Devonian calcschists and marbles, which exhibit mylonitized zones, isoclinal folds, and a NE-trending (N25-30 ${ }^{\circ}$ to $\mathrm{N} 40^{\circ}$ ) mineral-stretching lineation (fig.4g). At the west-northwestern border of the Pia Oac massif, along the road to Tinh Tuc, the décollement surface separates foliated Triassic metarhyolites and greywackes from the underlying Devonian marbles, both displaying a $\mathrm{N} 60^{\circ}$ to $\mathrm{N} 40^{\circ}$ stretching lineation.

\subsection{4. underthrusting.}

The main tectonic setting, largely exposed in the area South of Yen Minh to Bao Lam, and South of Song Nhiem, is marked by the underthrusting, under ductile conditions, of the Lower Triassic Formations beneath the Upper Paleozoic of the Northeastern Vietnam nappe (fig.4a). In many outcrops, the Triassic flysch is isoclinally folded (figs 3.e, 3.f).

To summarize, on one hand the Triassic series tectonically underlies the Upper Paleozoic of the Northeastern Vietnam nappe as this is exposed South of Yen Minh, and on the other hand it overlies, with evidence of differential tectonic movements, the Upper Paleozoic of the autochthonous domain, as this can be recognized to the North in the area of Dong Van. Elsewhere, in the Ngan Son and Pia Oac area (Song Hien zone) the same Triassic sediments rest directly over the Devonian by means of ductile décollement. This implies the existence of a Song Hien secondary nappe, made by the Triassic sediments and volcanosediments derived from the Song Hien rift. This confirms previous tectonic conclusions (Deprat 1915; Bourret, 1922). Furthermore, the opposite tectonic relationship of the Triassic schists, either lying beneath the Middle-Upper Paleozoic rocks of the main part of the nappe, South of Yen Minh, or over the similar deformed Devonian series of the Ngan Son sheet, temporarely require a succession of two tectonic episodes. It can be suggested first a décollement of the Triassic rocks which could have formed klippes, as in the Nui Ngan Son and second a major thrusting of the Upper Paleozoic over the Triassic, to form the main nappe.

\section{Age constraints on deformation and nappe emplacement}

A Lower Paleozoic tectonism - so-called « a Caledonian event » - is recognized in northernmost Vietnam, and in South China (Grabau, 1924, Ren, 1964, 1991; Zhao et al., 1996; Faure et al., 2009; Charvet et al., 2010), by the Lower Devonian regional unconformity (in South China the unconformable layers are of Mid-to Late Devonian age). The Triassic phase of ductile and synmetamorphic deformation, coeval with nappe emplacement, 
occurred before the unconformable deposition of the Upper Triassic to Early Jurassic sediments which form a large foreland basin in the southeastern part of the area (An Chau sector, fig.1) and are distributed into several isolated outcrops in the central part. The Lower Triassic and perhaps a part of the Middle Triassic formations are themselves involved in the tectonic development. Tertiary overprints are illustrated by the folding and thrusting of the Upper Triassic to Cretaceous series and by the strike-slip development of Neogene pull-apart basins. In the metasedimentary material, the Triassic tectonometamorphic event is not geochronologically constrained, due to the low-grade metamorphism that did not allow the development of micas of appropriate size for applying the Ar-Ar geochronological dating. Generally, the foliation surface is underlined by sericitic minerals, except around granitic intrusions such as the Phia Bioc and Pia Oac massifs, where biotite-bearing micaschists and paragneisses are present, as a result of thermal metamorphism.

Most of the available geochronological data come from samples collected in the gneissic core of the Song ChayDulong Massif. Other geochronological investigations have been carried out in the various magmatic intrusions, either deformed or not deformed, which are found within the Paleozoic and Triassic succession.

\subsection{Song Chay Massif}

Geochronological investigations combining different methods have been applied to the rocks of the massif, which underwent a complex thermal history from the time of their crystallisation to the time of their final exhumation:

From a multi-system geochronology applied on a single orthogneiss sample (Roger et al., 2000), U-Pb zircon dating indicates a $428 \pm 5 \mathrm{Ma}$, Silurian age, for the granite emplacement. Rb-Sr data on the same material yield $206 \pm 10$ and 176 $\pm 5,3$ cooling ages from muscovite and biotite repectively. Ar-Ar analyses on micas have revealed $190 \pm 8$ and $210 \pm 9$ Ma plateau ages on biotite and muscovite, respectively. All together these cooling ages are interpreted as corresponding to nappe stacking or exhumation that followed the top-to-north shearing. Theses ages are in agreement with the existence of the Yen Binh half-graben, which started to fill in the Late Triassic (see 3.2.2). Rapid cooling during the Tertiary, in particular documented by fission tracks analysis, was related to a final phase of exhumation.

Using Ar-Ar mica dating and apatite fission-tracks analysis from several samples collected along the same transect, Maluski et al. (2001) documented the thermal history of a N-S section of the massif. 236-234 Ma, and 200 to 165 Ma cooling ages have been obtained from muscovite from the southern and northern rims of the 
massif, respectively. These dates argue for slow to moderate uplift in the Jurassic, after the initial Triassic development of the flat-lying foliation. Fission-tracks analysis indicates that the massif experienced a rapid cooling during the 28-20 Ma time interval (Maluski et al., 2001). From monazite inclusions in garnet, Gilley et al., (2003), obtained in situ U-Th-Pb dating at $419 \pm 3$ and $380 \pm 7$ Ma, and a 255-203Ma age from matrix monazites.

In the Chinese Dulong sector of the massif, Yan et al. (2006) also found in the gneissic core U-Pb ages of $402 \pm 10$ and $436 \pm 12 \mathrm{Ma}$, corresponding to the crystallisation age of the granitic intrusion. U-Pb ages of $237 \pm 15$ Ma, from the interface with the overlying metasedimentary sequence, are interpreted to represent the major stage of metamorphism, coeval with extensional tectonics along a detachment fault. Ar-Ar analyses on amphibole separates yield the same $237 \pm 4,6$ Ma age, whereas biotite and muscovite separates yield younger well-defined plateau ages corresponding to a thermal overprint and a continued exhumation during the Jurassic to Cretaceous.

All the available geochronological results obtained on the Song Chay-Dulong massif are consistent. They indicate a long thermal history, starting with the magmatic emplacement of a granitic pluton in Silurian during an early Paleozoic event, and followed by the early-middle Triassic development of a flat-lying foliation and the onset of exhumation.

\section{2. granite and gabbro-syenite intrusions}

Geochronological constraints are also provided by the age of the magmatic rocks that intrude the sedimentary Paleozoic and Triassic formations of the northeastern Vietnam nappe system. The plutono-volcanic activity is mainly related to the Emeishan plume (Polyakov et al., 1999, Hanski et al., 2004) and took place into two distinct stages, according to new investigations (Tran Trong Hoa et al., 2008).

- An Early Permian stage is responsible in the Song Hien zone for the formation of the plagiolherzolite of the Suoi Cun massif, near Cao Bang, with a zircon U-Pb age of 262Ma, (but inherited zircons of Ordovician age are also identified). Gabbro-dolerites from the same massif yield a group of zircons corresponding to a similar Permian 266 \pm 3.7 Ma age.

- In a second stage, during the Late Permian and Early Triassic around 250 Ma, are emplaced the Nui Chua layered peridotite-gabbro complex (251 $\pm 3.4 \mathrm{Ma} \mathrm{U}$-Pb age on zircons for a gabbronorite) and the gabbro-syenite association (Tran Trong Hoa et al., 2008) of the Lo Gam and Phu Ngu zones (244 and 233 Ma ages have been found for the Luc Yen gabbro and Cho Don nepheline syenite, respectively). Ar-Ar dating on biotite (Tran 
Trong Hoa et al., 2008) from the undeformed high-alumina Ban Phuc granite of the Phia Bioc complex, which intrudes the Chodon gabbro-syenite, provides an Early Triassic plateau age of $250 \pm 1$ Ma. In the same time interval, rhyolites (from the bimodal volcanoplutonic association of the Song Hien rift) provide zircon grains of Early Triassic age (248+-4, $5 \mathrm{Ma})$.

These geochronological data are generally in good agreement with the field observations of geometric relationship between the magmatic rocks and the Paleozoic and Early Triassic strata. In the Song Hien Triassic zone the Permian age of the gabbronorite (and ultrabasites) is in accordance with the magmatic age of intrusion of these igneous rocks and not with their depositional age as olistoliths. The Early Triassic age of the Ban Phuc granite appears as a little bit too old with respect to the inferred metamorphic age of the surrounding metasedimentary country rocks, considering the implication of the Early Triassic and perhaps a part of the Middle Triassic in the tectonometamorphic event.

According to the available geochronological data from the Song Chay gneissic massif and other magmatic bodies, the ductile deformation and nappe emplacement in northeastern Bac Bo likely occurred during the Lower to Lower-Middle Triassic. Additional dating is needed, in particular the dating of the Pia Ma gneissic syenite to provide a direct age of the deformation and the coeval metamorphism.

\section{Nappe provenance and Song Chay suture zone}

The $\mathrm{N}$ to NE striking stretching lineation is interpreted as indicating the nappe transport direction. The top-to-the north sense of shear implies a southern provenance for the northeastern Vietnam nappe. This contradicts the opinion of Deprat (1915) who located the root zone of the "nappes preyunnanaises" to the West of the Song Chay massif.

Serpentinite bodies, already reported on the geological maps (GDMGV, 1973 and DGMV, 2000, Bac Quang map sheet), crop out with occurences of gabbros, volcanics and marbles, along the Song Chay Fault (at the northern border of the Day Nui Con Voi). As exposed in several outcrops near Pho Rang (Bao Yen), these elements are mixed within a pelitic and volcanic schistose matrix (Figs.5.i, 5.j), suggesting diapiric mélange in accretionary complexes (Barber and Brown, 1988). This zone would then appear as a new ophiolitic suture zone and would represent a good candidate for the origin of the Northeastern Vietnam nappe. However, several types of rocks expected in such a context are missing and the oceanic nature of the material in the mélange is not presently demonstrated. It is reasonable to infer a Triassic age for this mélange according to the fact that 
deformation and metamorphism to the North of the Song Chay Fault in the Song Chay gneiss and in the metasedimentary Paleozoic rocks is Triassic. New data are required to support this assumption. A southward subduction of the South China margin during the Upper Paleozoic beneath the present-day Day Nui Con Voi, where Triassic metamorphic ages have been reported (Searle, 2006), is also suggested as a working hypothesis, bearing in mind the Tertiary translation of this massif.

Our hypothesis challenges the interpretation of Cai and Zhang (2008) related to the existence of an ophiolitic suture in the Ba Bu sector of the South China-Northern Vietnam border zone. The material cropping out in this zone has been correlated with the mafic and ultramafic rocks lying along the Cao Bang fault (Hai Tran Thanh, 2008). But the attribution to ophiolite of these assemblages, including pillow lavas, is questionable, because of their alkaline geochemical character (Tran Trong Hoa et al., 2008). The pillow basalts and other magmatic rocks in this area have no oceanic signature. They are rather related to the intraplate Emeishan plume activity and have been emplaced in a continental intraplate setting (Polyakov et al., 1999; Hanski et al., 2004). Along the Cao Bang Fault those alkaline magmatic fragments represent olistoliths within the Lower Triassic sediments of the Song Hien rift basin. Furthermore, deep-sea sedimentary rocks, such as radiolarian chert, siliceous mudstone or pelagic limestone are also lacking in the so-called « Ba Bu ophiolites ». In Guangxi province of China, alkaline gabbro and diabase intrude the Carboniferous and early Permian carbonate developing a thermal aureole (W. Lin and M. Faure, unpublished observations).

The existence of a Triassic suture along Song Chay better fits with the tectonic and kinematic data, which have been obtained in our study. The Song Chay Fault zone would correspond to the Triassic boundary of the South China continental block (including Northeastern Vietnam), instead of the Song Ma zone and an intermediate continental fragment, more or less equivalent to the Song Da terrane mentioned in the literature, would have existed between the two sutures (fig.1, inset).

\section{Conclusion}

By revisiting and carefully checking the previous structural descriptions of northeastern Vietnam we confirm the validity of the interpretations proposed by J. Deprat one century ago (Deprat, 1915). Indeed, Deprat was right when establishing the structure of Tonkin as a pile of ductile nappes, formed in Triassic times and resting to the North over an autochthonous domain. In addition, we show that the Song Chay massif was involved in the same tectonic process, with an original flat-lying foliation, in the orthogneiss and its host 
sedimentary formations, being later refolded to give rise to the present-day antiform. At least in the Vietnamese side of the Song Chay massif, evidence for major detachment fault and metamorphic core complex is absent.

The new structural and kinematic data collected during this study indicate, throughout the Northeastern Vietnam nappe, a consistent top-to-the-N-NE sense of shear. This Triassic NE-vergent tectonic event in northern Vietnam can be correlated with the D2 event recorded in the Yunkai massif of South China (Lin et al., 2008); this event is marked by a similar development in Early Mesozoic time, prior to the Upper Triassic, of top-to-thenortheast ductile shearing and folding, coevally with amphibolite to greenschist facies metamorphism. Although not yet precisely dated, the pre-upper Triassic age of the main ductile event in northeastern Vietnam seems to be coeval or slighty younger than the ductile tectonics, dated around 250-240 Ma (Early Triassic) in the Truong Son Belt and Kontum Massif, South of the Song Ma suture zone.

The existence of nappes North of the Song Ma suture in the Song Da area, which have been called « Nappes de la Rivière Noire » by Deprat (1914), requires a similar checking. Post-Triassic thrusting onto Upper Cretaceous red beds have already been recognized in the area (Lacassin et al., 1999) but the unconformity of this Cretaceous formation on overturned Triassic marbles deformed by isoclinal folding in the area of Phong Tho/new Lachau (C.Lepvrier, unpubl. observations) gives a substantial credit to the existence of Triassic nappes in Northwestern Vietnam, comparable to those of Northeastern Vietnam.

A new zone of mélange including blocks of serpentinites, mafic volcanic rocks and marbles whitin a metasedimentary matrix of supposed Triassic age, has been recognized along the Song Chay Fault and has been tentatively interpreted as an oceanic suture, forming the Triassic tectonic boundary of the South China block. Considering the southern provenance of the northeastern Vietnam nappe, this Song Chay suture could represent the location of the root zone.

\section{Acknowledgments}

This article is the contribution ${ }^{\circ}$ of the ISTeP, UMR 7193 of University P\&M Curie. Claude Lepvrier thanks his Institute and AUF (“Action Universitaire pour la Francophonie”, bureau Asie Pacifique in Hanoi) for financial support. Michel Faure has benefited of the help(TO BE PRECISED)...Field investigations have been supported, on the Vietnamese side, by the National Foundation for Sciences and Technology Development of Vietnam for the projects: 105.01 (Nguyen Van Vuong); 105.01.53.09 (Vu Van Tich);105.06.60.09 (Ta Hoa Phuong). 
The authors thank the reviewers: Dr. Masatoshi Sone, A.J. Barber and J. Charvet for their constructive and thoughtful comments that have greatly allow an improvement of the paper.

\section{References}

Barber A.J. et al. 1986. Mud volcanoes, shale diapirs, wrench faults and melanges in accretionary complexes, Eastern Indonesia. American Association of Petroleum Geologists, 70, 1729-1741.

Barber A.J. and Brown, 1988. Mud diapirism: The origin of melanges in accretionary complexes? Geology Today, 4, 89-94.

Bourret, R., 1922. Les Nappes dans le Nord-Est du Tonkin. C. R. Acad. Sc., t.174, 406-408.Bourret, R., 1922. Etudes géologiques sur le Nord-Est du Tonkin (Feuilles de Bao Lac, Cao Bang, Ha Lang, Bac Kan, That Khé et Loung Tcheou. Bull. Serv. Géol. de l’Indochine, Vol. XI, Fasc.I, 317pp.

Cai, X. and Zhang, K.J., 2009. A new model for the Indochina and South China collision during the Late Permian to the Middle Triassic. Tectonophysics 467, 1- 4, 35-43.

Carter, A., Roques, D., Bristow, C., Kinny, P., 2001. Understanding Mesozoic accretion in Southeast Asia: significance of Triassic thermotectonism (Indosinian orogeny) in Vietnam, Geology 29, 211-214.

Carter, A., Clift, P.D., 2008. Was the Indosinian orogeny a Triassic mountain building or a thermotectonic reactivation event? C. R. Geoscience 340, 83-93.

Charvet J., Shu LS., Faure M., Choulet, F., Wang, B., Le Breton N., 2010. Structural development of the Lower Paleozoic belt of South China: genesis of an intracontinental orogen. J. of Asian Earth Sc., 39, 309-330.

Deprat, J., 1914. Etude des plissements et des zones d’écrasement de la Moyenne et de la Basse Rivière Noire. Mém. Serv. Géol. de l’Indochine, Hanoi, vol.III, fasc.IV, 59 pp.

Deprat, J., 1915. Etudes géologiques sur la région septentrionale du Haut-Tonkin (feuilles de Pa Kha, Ha Giang, Ma-Li-Po, Yen Minh). Mém. Serv. Géol. de l’Indochine, vol IV, fasc. IV, 174pp.

Deprat, J., 1917. La zone frontale des nappes preyunnanaises dans les régions de Bao Lac et de Cao Bang. C.R.Ac.Sc., t. $165, n^{\circ} 6,243-246$.

Dovjikov, A.E., 1965. Geological map of North Vietnam, scale 1:500 000, with Memoir 650 p., Science and Technics Publishing House, Hanoi.

Faure M., Shu L.S., Wang, B., Charvet J., Choulet F., Monié P., 2009. Intracontinental subduction: a possible mechanism for the Early Palaeozoic Orogen of SE China. Terra Nova, 21, 360-368.

Fontaine, H. and Workman, D.R., 1978. Review of the geology and mineral resources of Kampuchea, Laos and Vietnam, in Nutalaya (Ed.), Proceedings of the Third Regional Conference on Geology and Mineral Resources of Southeast Asia, Asian Institute of Southeast Asia, Bangkok, 541-603. 
Fromaget, J., 1941. L’Indochine française, sa structure géologique, ses roches, ses mines et leurs relations possibles avec la tectonique. Bull. Serv. Géol. de l’Indochine 26 (2), 1-140.

DGMV (Department of Geology and Mineral Resources of Vietnam, Hanoi), 2000. Geological map of Kim Binh - Lao Cai (F- 48-VIII \& F-48-XIV): 1:200, 000 scale.

DGMV, 2000. Geological map of Ma Quan (F-48-IX): 1:200, 000 scale.

DGMV, 2000. Geological map of Bao Lac (F-48-X): 1:200, 000 scale.

DGMV, 2000. Geological map of Chinh Si-Long Tan (F-48-XI \& F48-XVII): 1:200, 000 scale.

DGMV, 2000. Geological map of Lang Son (F-48-XIII): 1:200, 000 scale.

DGMV, 2000. Geological map of Bac Quang (F-48-XV): 1:200, 000 scale.

DGMV, 2000. Geological map of Bac Kan (F-48-XVI): 1:200, 000 scale.

DGMV, 2001. Geological map of Tuyen Quang (F-48-XII): 1:200, 000 scale.

GDMGV, (General Department of Mines and Geology of the Democratic Republic of Vietnam), 1973. Geological map of Vietnam (the North part), 1:1 000,000 Tran Van Tri, Ed. in Chief.

GDMGV, 1979. Explanatory note to the geological map on 1:1 000, 000 scale, in Geology of Vietnam (the North part), Science and Technology Publishing House, Hanoi, Tran Van Tri (Ed.).

GDMGV, 1988. Geological map of Kampuchea, Laos and Vietnam, 1:1 000, 000, Phan Cu Tien Ed. in chief.

Gilley, L.D., Harrison, T.M., Leloup, P.H., Ryerson, F.J., Lovera, O.M., Wang, J.H., 2003. Direct dating of leftlateral deformation along the Red River shear zone, China, Vietnam. Journal of Geophysical Research, 108, doi :10.1029/2001JB0011726.

Grabau, A., 1924. Stratigraphy of China, part I, Paleozoic and older, Geol. Surv of Agric and Commerce, Peking.

Hai Tran Thanh, 2008. New discovery on the existence of oceanic crust in northeastern Vietnam and its implication to the tectonic evolution of Paleotethys. Abstract 33th IGC-Oslo, Norway.

Hanski, E., Walker, R.J., Huhma, H., Polyakov, G.V., Balykin, P.A., Hoa, T.T. and Phuong, N.T., 2004. Origin of the Permian-Triassic komatiites, northwestern Vietnam. Contr. Miner. Petrol. 147 (4), 453-469.

Hutchison, C. S., 1989. Geological Evolution of South-East Asia, Oxford Monographs on Geology and Geophysics, vol.13, Clarendon Press, Oxford, UK, 368 pp. 
Jacob, C., 1921. Etudes géologiques dans le Nord-Annam et le Tonkin. Bull. Serv. Géol. de l’Indochine, Vol. X, Fasc.I.

Jacob, C. et Bourret, R., 1920. Itinéraire géologique dans le Nord du Tonkin. Bull. Serv. Géol. de l’Indochine, Vol. IX, Fasc. I, 47p.

Jacob, C. et Dussault, L., 1925. Exploration géologique dans le Haut-Laos. Bull. Serv. Géol. de l’Indochine, Vol. XIII, Fasc.IV, 118 pp.

Kat, N.D., 1972. Main tectonic features of North Vietnam (translation from Russian ; Geotectonics, $\mathrm{n}^{\circ} 4$, 245250. cf deep-seated faults.

Lacassin, R., Leloup, H., V. Trinh, Tapponnier, P., 1998. Unconformity of red sandstones in North Vietnam, field evidence for Indosinian orogeny in northern Indochina? Terra Nova 10, 106-111.

Lepvrier, C., Maluski, H., Nguyen Van Vuong, Roques, D., Axente, V., Rangin, C., 1997. Indosinian NWtrending shear zones within the Truong Son belt (Vietnam): 40Ar-39Ar Triassic ages and Cretaceous to Cenozoic overprints. Tectonophysics 283, 105-127.

Lepvrier, C., Nguyen Van Vuong, Maluski, H, Phan Truong Thi, Van Vu Tich, 2008. Indosinian tectonics in Vietnam. C. R. Geoscience 340, 94-111.

Lepvrier, C., Faure, M., Nguyen, V. V., Vu V. T., Ta T. T., 2009. Triassic north-directed thrust nappes in northeastern Vietnam. IAGR Annual Convention \& 6th International Symposium on Gondwana to Asia, Hanoi. Conference Series 8, 46-47.

Lin, W., Wang, Q. and Chen, K., 2008. Phanerozoic tectonics of South China block: New insights from the polyphase deformation in the Yunkai massif. Tectonics, vol.27, TC6004, p.1-16.

Maluski, H., Lepvrier, C., Jolivet, L., Carter, A., Roques D., Beyssac, O., Ta T. T., Nguyen D. T. and Avigad, D., 2001. Ar-Ar and fission track ages in the Song Chay massif: Early Triassic and Cenozoic tectonics in northern Vietnam. J. Asian Earth Sciences 19, 233-248.

Metcalfe, I., 2002. Permian tectonic Framework and paleogeography of SE Asia. J. Asian Earth Sci. 20, 551566.

Morgunov, Y.G., 1970. Basic features of tectonics of North Vietnam (translation from Russian). Int. Geol. Rev, v.12, 1333-1345.

Nakano, N., Osanai, Y., Nguyen Thi Minh, Miyamoto, T., Hayasaka, Y, Owada, M., 2008. Discovery of Highpressure granulite-facies metamorphism in northern Vietnam: Constraints on the Permo-Triassic Indochinese continental collision tectonics. C. R. Geoscience 340, 127-138.

Nakano, N., Osanai, Y., Sajeev, K., Hayasaka, Y., Miyamoto, T., Nguyen Thi Minh, Owada, M., 2010. Triassic eclogite from northern Vietnam: inferences and geological significance. J. Metamorphic Geol. 28, 59-76. 
Polyakov, G.V, Tran Trong Hoa, Akimtsev, V.A., Balykin, P.A., Ngo Thi Phuong, Hoang Huu Thanh, Tran Quoc Hung, Bui An Nien, Tolstykh, N.D., Glotov, A.I., Petrova, T.E. and Vu Van Van, 1999. Ore and geochemical specialization of Permo-Triassic ultramafic-mafic complexes in North Vietnam. Geologiya i Geofizika (Russian Geology and Geophysics, 1474-1487.

Ren, J.S., 1964. A preliminary study on pre-Devonian geotectonic problems of southeastern China. Acta Geologica Sinica 44 (4), 418-431.

Ren, J.S., 1991. On the geotectonics of southern China. Acta Geologica Sinica 4 (2), 11-130.

Roger, F., Leloup, P.H., Jolivet, M., Lacassin, R., Tranh, P.T., Brunel, M., Seward, D., 2000. Long and complex thermal history of the Song Chay metamorphic dome (Northern Vietnam) by multi-system geochronology. Tectonophysics 321, 449-466.

Searle, M.P., 2006. Role of the Red River Shear zone, Yunnan and Vietnam, in the continental extrusion of SE Asia. Journal of the Geological Society, London, 163, 1025-1036.

Staritskiy, Y.G., Maymin, Y.S. and Trofimov, V.A., 1973. Tectonic development of North Vietnam (translation from Russian). Int. Geol. Rev, v.15, n¹2, 1381-1390.

Tapponnier, P.G., Peltzer, G., Armijo, R., 1986. On the mechanisms of the collision between India and Asia. In: Coward, P.P., Ries, A.C. (Eds.), Collision tectonics, Geological Society Special Publication, vol.19, pp.115-157.

Tran Trong Hoa, Tran Tuan Anh, Ngo Thi Phuong, A.E .Izokh, G.V. Polyakov, P.A. Balykin, Chin Ying Lan, Hoang Huu Thanh, Bui An Nien and Pham Thi Dung., 2004. Gabbro-syenite associations of East Bac Bo structures: evidences of intra-plate magmatism ? J. of Geology, series B, n²3, 12-25.

Tran Trong Hoa, A. E. Izokh, G.V. Polyakov, A.S. Borisenko, Tran Tuan Anh, P.A. Balykin, Ngo Thi Phuong, S.N. Rudnev, Vu Van Van and Bui An Nien, 2008. Permo-Triassic magmatism and metallogeny of Northern Vietnam in relation to the Emeishan plume. Russian Geology and Geophysics 49, 480-491.

VNU Publishing House, 2006. The stratigraphy of Vietnam. Tong-Dzuy Thanh, Vu Khuc, editors, pp.528.

Yan, D.P., Zhou Mei-Fu, Wang, C.Y. and Xia B., 2006. Structural and geochronological constraints on the tectonic evolution of the Dulong-Song Chay tectonic dome in Yunnan province, SW China. Journal of Asian Earth Sciences 28, 332-353.

Zeil, G., 1907. Contribution à l'étude géologique du Haut Tonkin (feuilles de That Khe, Pho Binh Gia et Loung Tcheou. Mém. Soc. Géol. de France, 4éme Série, Tome I, Mém.3, p. 5-18, 1 carte et 1 planche de coupes.

Zhao, X., Allen, M.B., Whitham, A., Price, S., 1996. Rift-related Devonian sedimentation and basin development in South China. Journal of Southeast Asian Earth Sciences 14, 37-52. 


\section{Figure Captions}

Fig.1 - A. Structural and kinematic map of Northeastern Vietnam (E Bacbo). Drawn from the 1: 1 000,000 geological map of Vietnam (Northern part) and from the 1: 200, 000 geological maps of Bac Quang, Ma Quan, Bao Lac, Bac Kan, Tuyen Quang, Yen Bai, Chinh Si-Long Tan, Lang Son, Hai Phong; lines A to D refer to the cross-sections of Fig.2. 1: Day Nui Con Voi metamorphic zone (gneisses, micaschists, amphibolites; 2: Song Chay gneissic rocks of the Northeastern Vietnam nappe with trace of foliation; 3: Permo-Triassic granite and syenite intrusions (deformed or not deformed); 4: gabbros and ultramafic bodies (either intrusives in the Paleozoic or forming olistoliths in the Lower Triassic); 5: Lower to Upper Paleozoic rocks of the autochthonous domain; 6: Lower Triassic sedimentary rocks and interbedded felsic effusives (tuffs, rhyolites) of the Song Hien Formation, including olistoliths (gabbros, pillow-lavas, marbles); 7: Lower to Upper Paleozoic metasedimentary rocks (marbles and schists) of the Northeastern Vietnam nappe (including the Nui Ngan Son Massif) and forming the Neoproterozoic and Lower Paleozoic metasedimentary host rocks of the Song Chay gneissic massif; 8: Middle Triassic felsic sedimentary-volcanic rocks and unconformable Upper Triassic to Lower Jurassic terrigenous Formations; 9 : Upper Cretaceous red beds; 10: Neogene basins (along the Song Chay and the Cao Bang-Lang Son-Tien Yen strike-slip faults). a: Cao Bang strike-slip fault segment and adjacent olistoliths of mainly magmatic rocks within the Lower Triassic Song Hien Formation; b: Song Chay strike-slip fault and adjacent zone of mélange (ophiolites?), consisting in blocks of serpentinite, volcanics, marbles within a matrix of likely Triassic age;c: Northeastern Vietnam Thrust (NVT); d: basal décollement of the Lower Triassic Song Hien nappe; e: normal fault (Yen Binh half-graben); f: steep, medium or low dip of the bedding/foliation (S0/S1) and shear planes; g: isoclinal fold axes and microfolds within the nappe; h: ductile microstructures and shear criteria - normal shear (southern border of the Song Chay Massif - L1, stretching and mineral lineation (top-to-thenorth-northeast sense of shear); arrows point to sense of shear of the upper part - L2, metric scale upright fold and crenulation lineation.

B - Inset: continental blocks and sutures zones including the inferred Song Chay suture (this study) and the intermediate continental piece between Indochina and South China (the latter geologically including northeastern Vietnam). Box indicates the study area. CM: Chang Mai; CR: Chang Rai; D: Dien Bien; DN: Danang; H: Hanoi; Hp: Haiphong; HCM: Ho Chi Minh city, L: Loei; LP: Luang Phrabang; N: Nan; P. Phetchabun; PP: Pnomh Penh; U: Uttaradit; V: Vientiane; Faults: DBF: Dien Bien Phu Fault; RF:Ranong Fault RRF: Red River fault; SCF: Song Ca Fault; TPF: Three Pagodas Fault;WCF: Wang Chao Fault. 
Fig.2 - Cross-sections through northeastern Vietnam (see location of A, B, C and D lines on Fig.1). Legends equivalent to legends of Fig.1; 1: Nui Con Voi metamorphic zone (gneiss, micaschists, amphibolites); 2: Song Chay orthogneissic massif within the Lower Paleozoic of the northeastern Vietnam nappe; 3: granitic and syenitic intrusions; 4: gabbros and ultramafic bodies; 5: Lower to Upper Paleozoic Formations of the autochtonous domain, deformed by upright to slightly inclined folds with locally axial cleavage; 6: ductilely deformed Lower Triassic of the Song Hien Formation (argilleous to marly shales and limestones, locally cherty beds, siltstones, sandstones, in part showing turbiditic facies, and interbedded volcanics, mainly felsics); it locally includes olistoliths of intrusives (gabbros, pillow-lavas...) and sedimentary rocks; 7: isoclinally folded Lower to Upper Paleozoic (mainly marbles) of the northeastern Vietnam nappe, including ductilely deformed magmatic bodies (Pia Ma syenitic gneiss); 8: Upper Triassic to Lower Jurassic terrigenous Formations; 9: Cretaceous detrital red beds Formation; 10: Neogene along Song Chay and Cao Bang-Lang Son-Tien Yen Faults; a: olistoliths of pillow lavas, gabbros, marbles from the previous Song Hien rift, tectonically intercalated, along the Cao Bang-Lang Son-Tien Yen fault, within the Lower Triassic Song Hien Formation; b: Song Chay Fault Zone: mélange including various blocks (serpentinite, volcanics, marbles, siliceous mudstones) in a schistosed matrix of supposed Triassic age; c: Northeasten Vietnam Thrust (NVT); d: décollement at the base of the Song Hien nappe; e: other faults: reverse, normal and strike-slip faults.

Fig.3 - Field photographs of tectonic structures from the Triassic of the « Song Hien » nappe and from the Paleozoic to the Triassic sedimentary succession in the autochthonous domain. GPS locations of the photographs are given on the right side. Same notations for figs. 4 and 5. a - pillow basalts interpreted as olistoliths (East of Cao Bang city); b - tectonized synsedimentary mélange made of various olistoliths (pillow lavas, serpentine, limestones) that are mixed with the Lower Triassic sediments of the Song Hien rift and remobilized by the Cao Bang strike-slip fault (East of Cao Bang city); c - block of limestone within the schistosed Lower Triassic in the area of Song Nhiem; d - sheared synsedimentary mélange of Lower Triassic age outcropping East of the Na Ri horst; e - isoclinal folding in the Lower Triassic flysch-type Song Hien Formation, overthrusted by the main nappe (road to the South of Yen Minh, near the Na Khe pass); $\mathrm{f}$ - north-verging folds and thrusts in Lower Triassic conodonts-bearing (M.Caridroit, personal communication) siliceous mudstones, (road between Bao Lam to Bao Lac along Song Gam); g - northeast-verging, decameter-scale fold in the flysch-type Lower Triassic Formation outcropping East of Cao Bang; $\mathrm{h}$ - upright tight folds in the Devonian of the autochthonous domain (road from Meo Vac to Ma Pi Leng); i - north-vergent folds and subsequent cross-cutting thrusts affecting the 
Devonian limestones (Si Phai Formation) near Ma Pi Leng; j - synschistosed upright fold in the Devonian, East of Dong Van.

Fig.4 - Outcrop photographs from the Paleozoic Formations: microfolds, planar and linear structures related to the emplacement of the Northeastern Vietnam nappe. a - panoramic southward view over the front of the nappe (NVT), overthrusting the Lower to Middle Triassic (Song Hien Formation) of Yen Minh city; b - mylonitic deformation in the Devonian marbles at the sole of the nappe (area of Lung Ho, Phuong Thuong); c - isoclinal folding in the Devonian siliceous limestones showing stretched limbs and hinges (Ba Be Lake, road to Cho Don) ; see Bourret 1922, pl.VII, C, for comparison; d - isoclinal folds in the Middle Devonian of Bao Lam (road Bac Me to Bao Lac, along Song Gam); e - intrafolial isoclinal folds in the Devonian limestones (road from Cho Ra to Boc Bo); $\mathrm{f}$ - foliated syenite of the Pia Ma intrusion (vicinity of Da Vi); g - stretching/mineral lineation in Devonian marbles (western flank of the Pia Oac granite massif); $\mathrm{h}$ - superimposed deformation in the Middle Paleozoic near Na Ban, western flank of the Pia Oac massif : foliation S1 170/50W, isoclinal fold parallel to stretching lineation (L1) with pyrite grains tails (pitch $40^{\circ} \mathrm{S}$ ) and secondary crenulation (L2) with pitch $25^{\circ} \mathrm{N}$; i - isoclinal folds (oblique view) affecting the Lower Paleozoic (Ordovician ), in the cliff bordering Bac Kan to the East; $\mathrm{j}$ - metric to decametric isoclinal fold, with axis parallel to the regional stretching lineation in the Lower Paleozoic (road Ha Giang to Bac Me).

Fig. 5 - Field scale photographs related to the main phase of the Triassic deformation in the Song Chay massif and related to the Song Chay mélange zone. a - slightly-dipping augen-gneisses with asymmetrical K-feldspars indicating a top-to-the-north shearing (area of Xi Man); b - laminated limestones (Cambrian) with pressure shadows forming stretched tails of Quartz (western flank of the Song Chay massif); c - south-dipping S-C structures in the Song Chay orthogneiss, with asymmetric K-feldspar porphyroclasts, showing a top-to-the-north sense of shear (road from Yen Binh to Xua Minh; d - ductile normal shearing marked by shear bands in the Lower Paleozoic micaschists at the border between the Song Chay gneisses and the Upper Cretaceous Yen Binh half-graben; e - W-dipping S0/S1 lower Paleozoic strata forming the western limb of the Song Chay antiform, North of Bac Ha landscape; the repetition of calcareous crests is likely due to kilometer-scale folding ; $\mathrm{f}$ - S0/S1 planar stucture in Cambrian limestones, with a level of quartz porphyroclasts showing asymmetrical tails and a top-to- the north shear sense (oblique-normal sense), western limb of the Song Chay antiform; g - meter-scale isoclinal fold with 160 axial trend, in the W-dipping Cambrian limestones at Bac Ha (western flank of the 
massif); h - meter-scale isoclinal fold with north axial trend, in the Devonian limestone near Vi Xuyen (eastern flank of the massif); i- inferred Song Chay suture zone: tectonized mélange comprising serpentinite, volcanics, pelitic matrix; $\mathrm{j}$ - inferred Song Chay suture zone: blocks of serpentinite, limestones in a schistosed matrix of likely Triassic age, made of siliceous shales. 


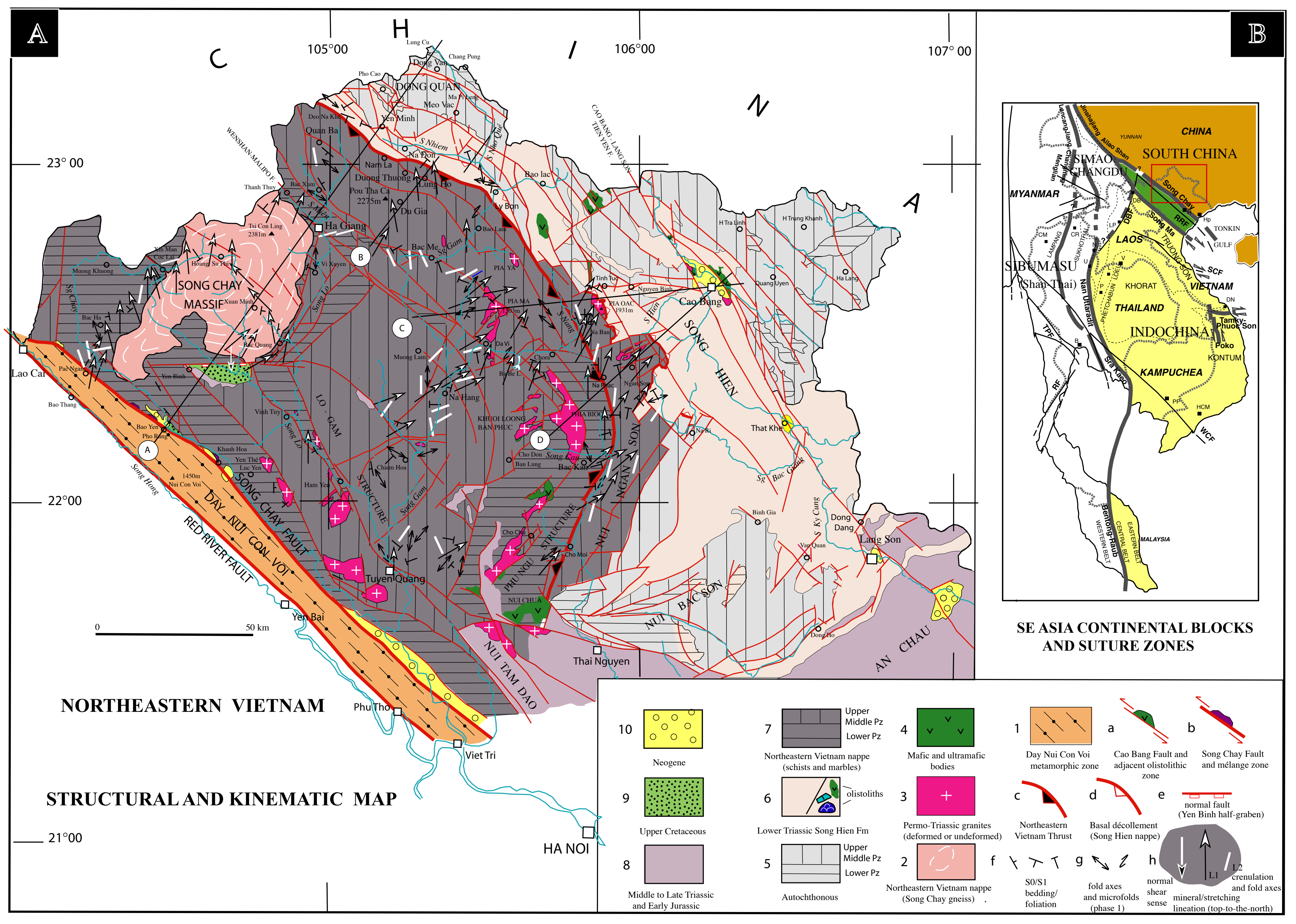


Wenshan/

Malipo Fault
Song Lo

\section{NNE}

Day Nui Con Voi | Song Chay

Song Chay Massif

Song Chay Song Lo

Dong Van plateau
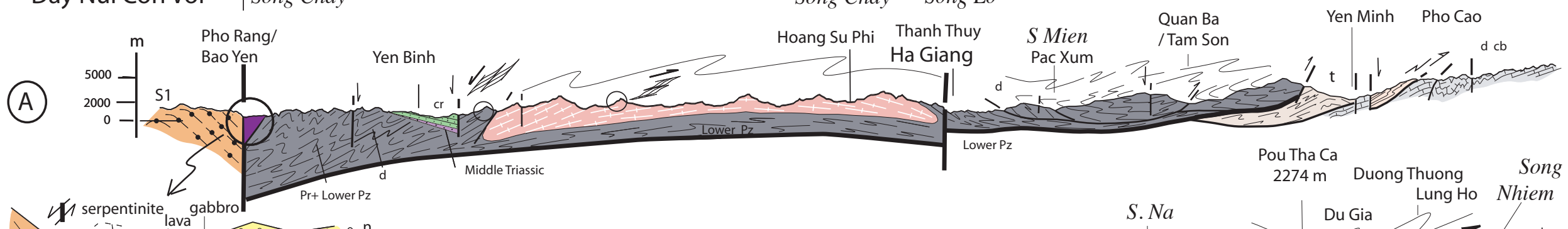

?

(it) 11

siliceous
mudstone

triassic matrix ?

10

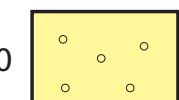

7

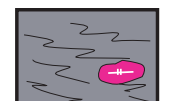

4

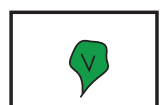

Neogene Northeastern Vietnam nap (schists, marbles,gneiss)

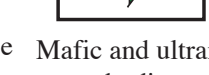
bodies

Cao Bang Fault Song Chay

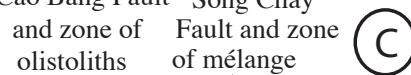

9

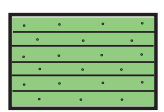

Upper Cretaceous

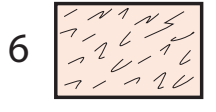

Lower Triassic 3

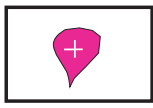

c

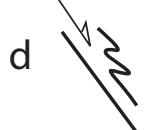

Basal décollement
(Song Hien nappe)

8

5
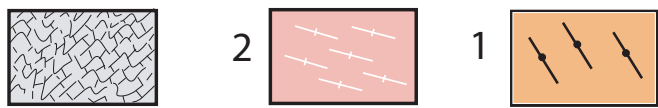

$e^{1 /} b^{2}$

Autochthonous $\begin{gathered}\text { Northeastern Vietnam na } \\ \text { (Song Chay gneiss) }\end{gathered}$

(B)

Middle to Late Triass and Early Jurassic

SW
Permo-Triassic granite

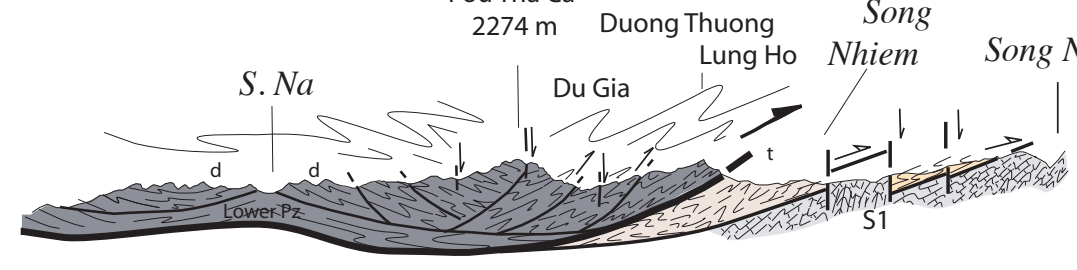

Nui Tong Tinh

$$
\text { Pia Oac }
$$

S. Nang $1531 \mathrm{~m}$ Nguyen Binh

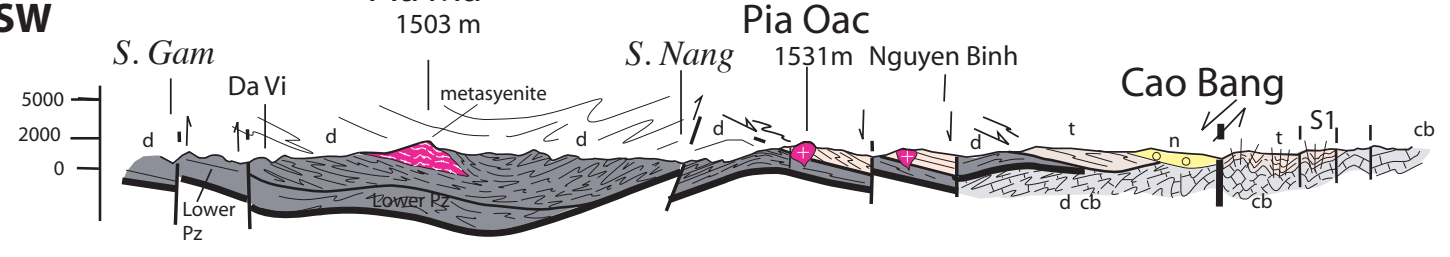

Phia Bioc

NE

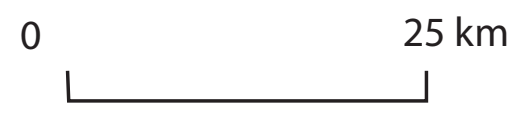

Ngan Son

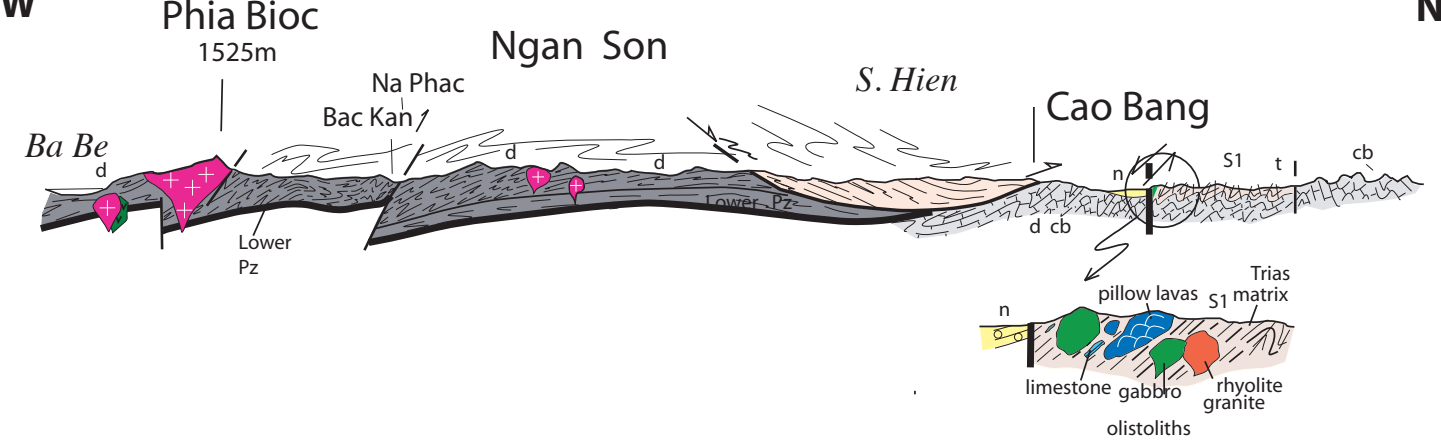



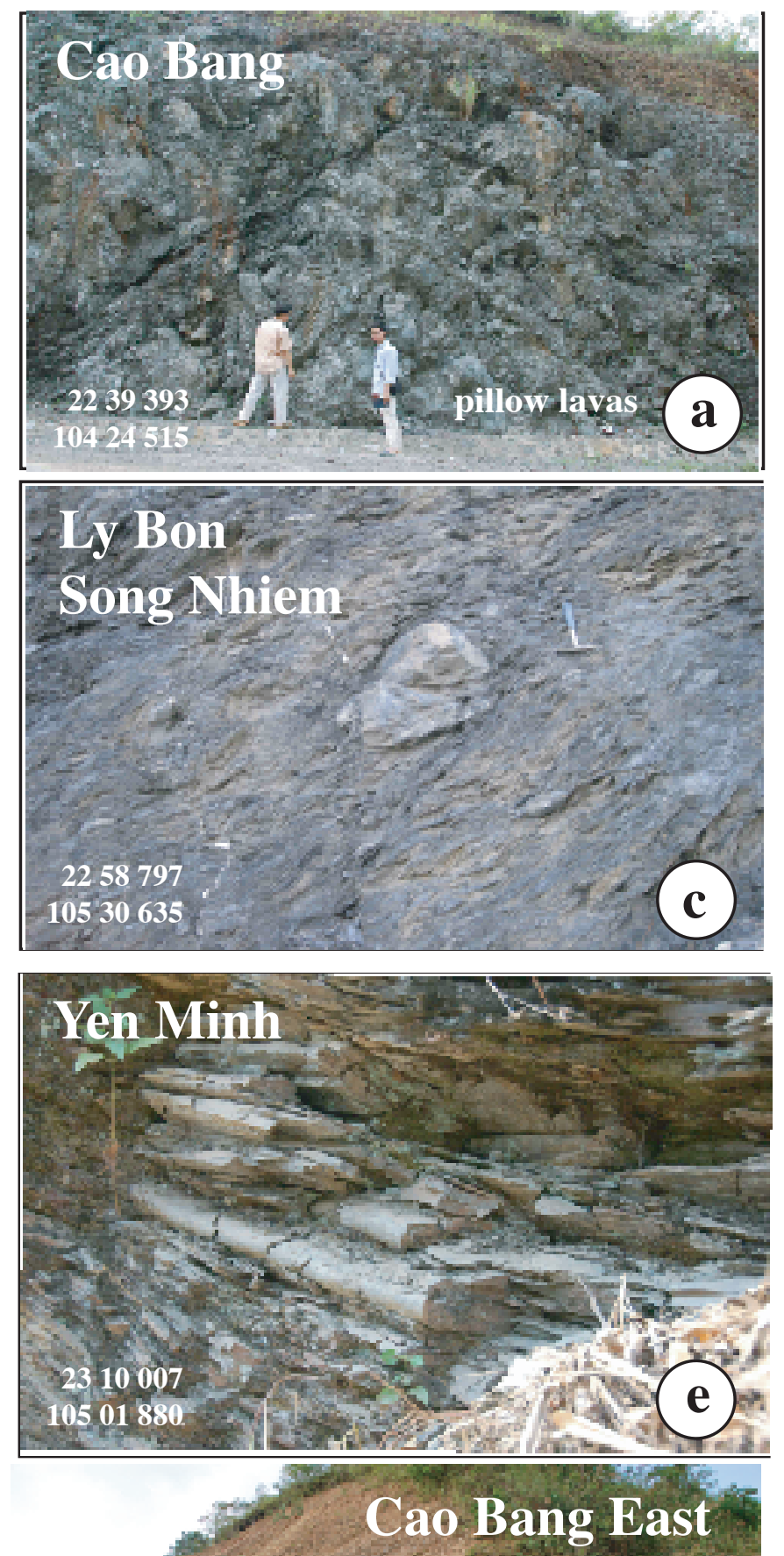

2242010

10617300

(g)

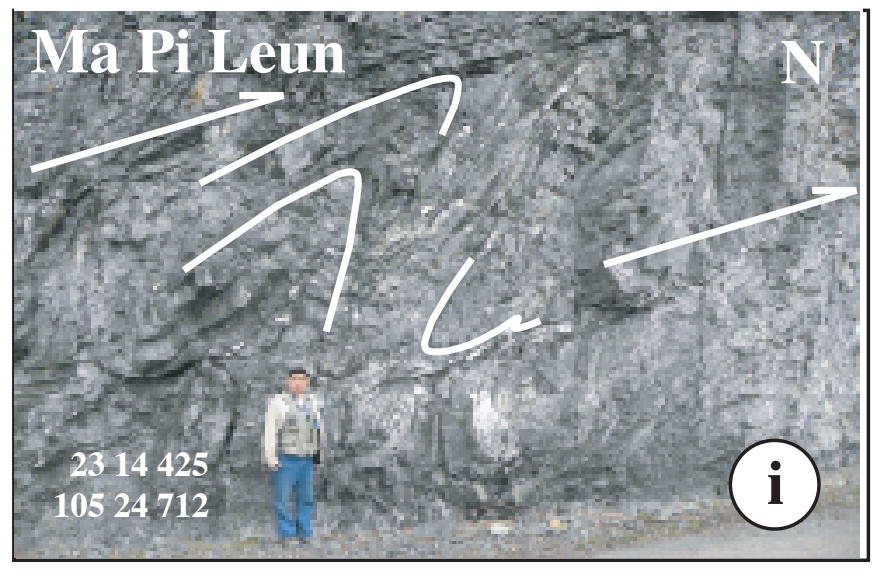

\section{Caobang}

E
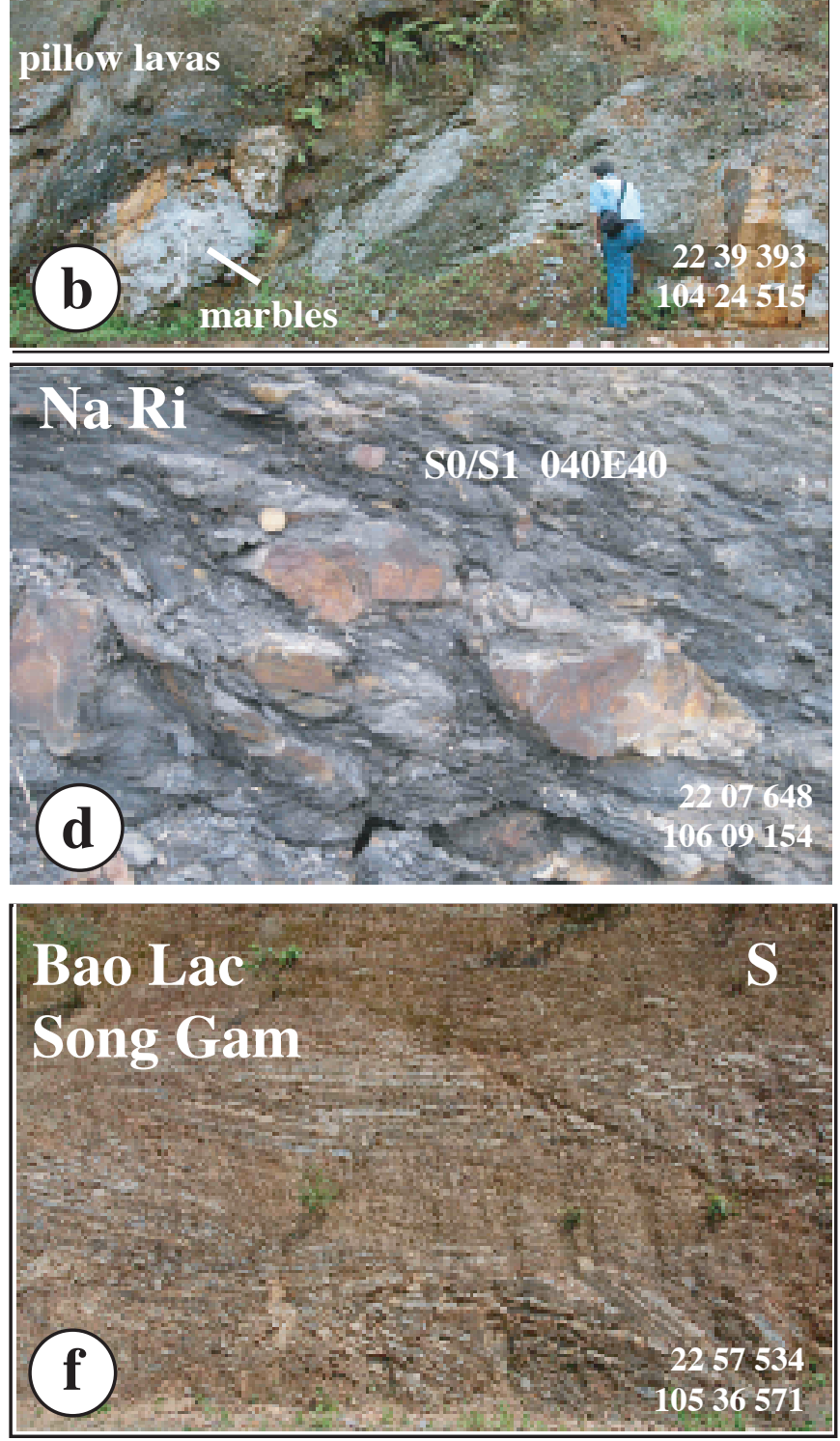

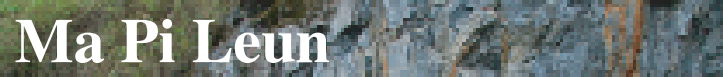
Meo Vac.
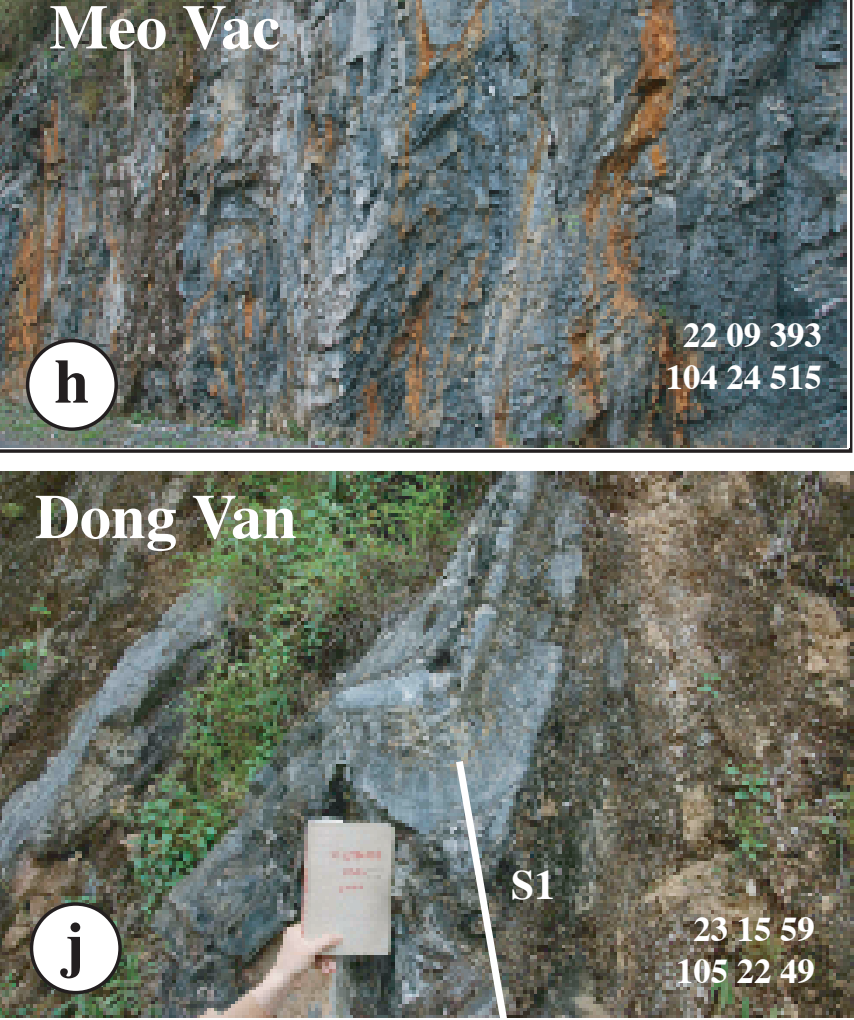

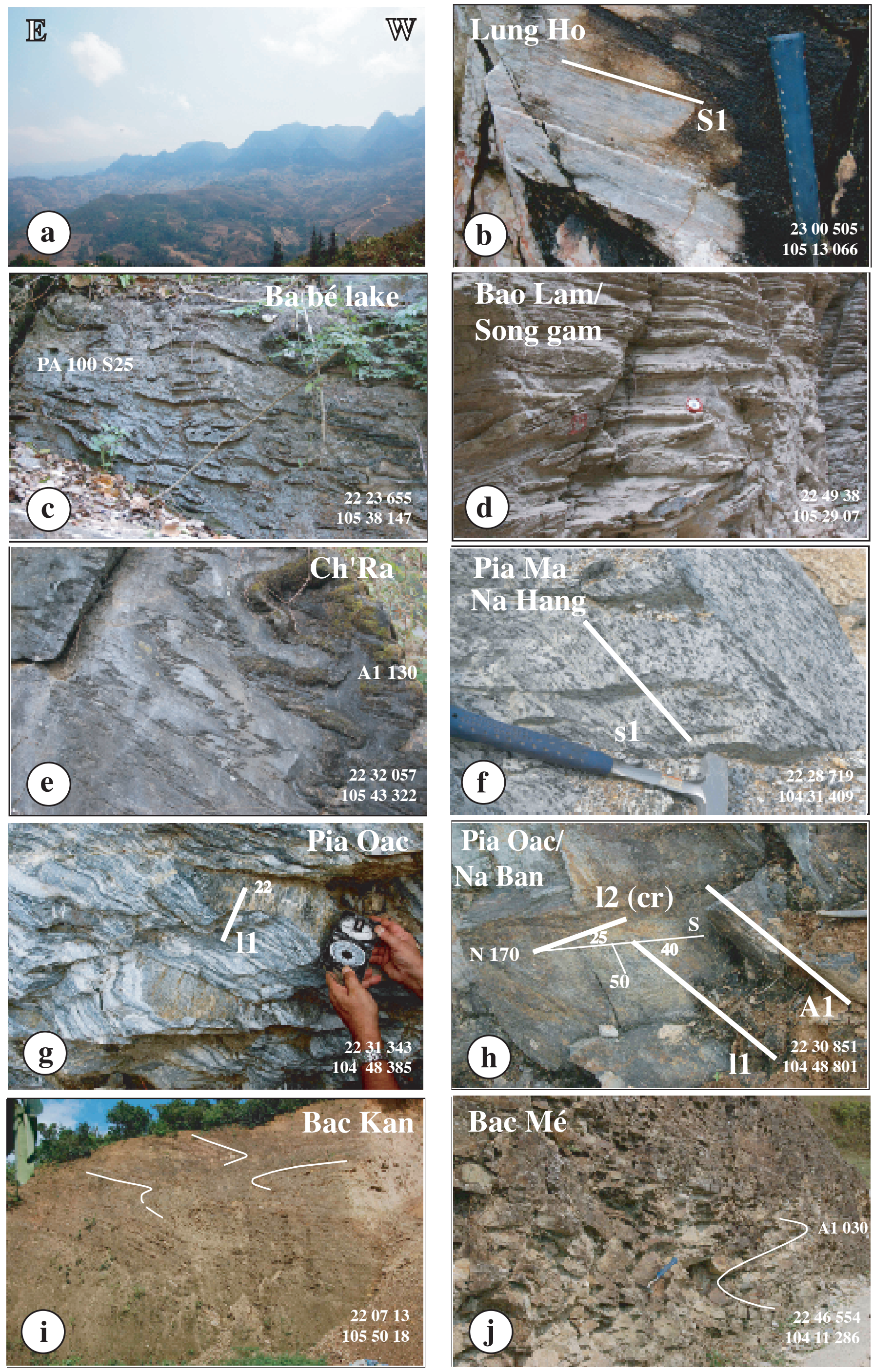

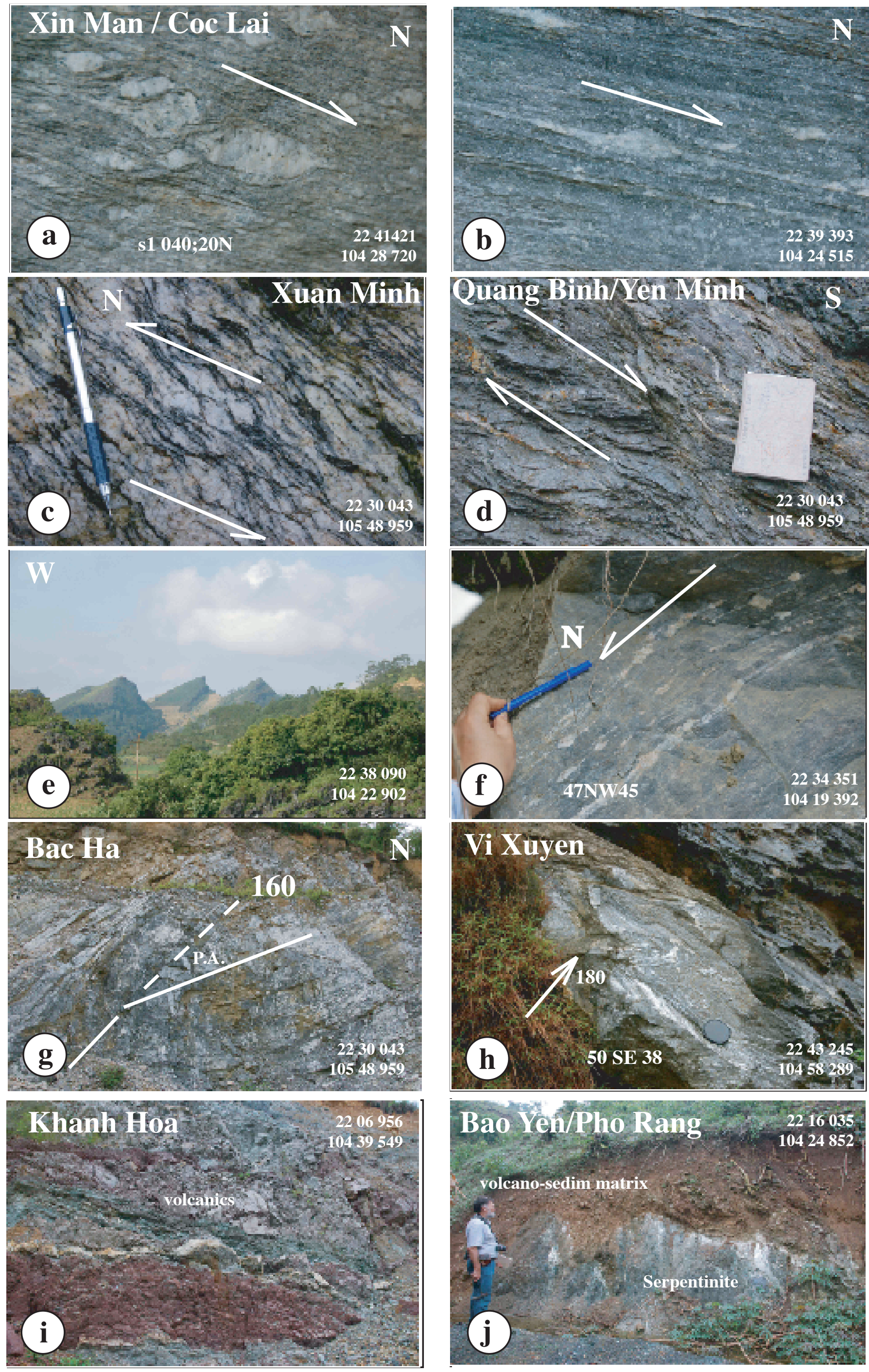